\title{
THE SPECTRUM OF WISDOM AND ESCHATOLOGY IN THE EPISTLE OF JAMES AND 4QINSTRUCTION
}

\author{
Darian Lockett
}

\begin{abstract}
Summary
One line of current research in the Epistle of James focuses upon the inter-relationships between traditional wisdom, prophetic, and eschatological material. In support of this line of inquiry this article investigates the combination of eschatological and sapiential concerns in James by comparing James with the intertestamental Jewish wisdom document 4QInstruction. In comparing literary forms, and sapiential and eschatological themes, the thesis is advanced that both texts incorporate traditional sapiential themes within an eschatological world-view and, therefore, James, as wisdom paraenesis, is not novel in combining these two traditions.
\end{abstract}

\section{Introduction}

James has had a chequered past in the history of its reception. It has been called a 'right strawy epistle' ${ }^{1}$ due to its lack of reference to Christ, it has been marginalized in light of its seeming contradiction of Pauline teaching, it has resisted most attempts at structural analysis, and many have been perplexed over the question of the letter's genre, not to mention if the text represents a 'real' letter at all. ${ }^{2}$ In the midst of

\footnotetext{
1 Compared with the writings of Paul which 'show thee Christ', Luther labelled James an 'epistle of straw' and thus did not include the letter among the 'chief books' of the canon (Preface to the New Testament, 1522; cf. Luther's Works, vol. 35: 362).

2 For a most serviceable account of the reception history of James see L. T. Johnson, Brother of Jesus, Friend of God (Grand Rapids: Eerdmans, 2004): 39-84; The Letter of James: A New Translation with Introduction and Commentary (AB, 37A; New York: Doubleday, 1995): 124-60.
} 
these interpretive difficulties lies the question of whether or not James should be considered wisdom literature especially in light of the eschatological material present in the text. In recent English-language scholarship the sapiential versus eschatological character of James has been brought to the forefront. On one hand, Patrick Hartin, arguing for a close connection between James and Q, claims that the Wisdom tradition controls the prophetic and eschatological elements found in James. ${ }^{3}$ On the other hand, Todd Penner argues that, through an inclusio structure of the letter's opening and closing sections (a 'framework' device), the eschatological material shapes and organizes the sapiential traditions. ${ }^{4} \mathrm{He}$ asserts that 'it is precisely those scholars who fail to recognize the contextual importance of the [eschatological] framework of the main body who most often insist that James is a wisdom document, not just formally, but conceptually as well'. ${ }^{5}$ In the end, both of these views betray an underlying assumption, namely that the material must be strictly categorized as either wisdom or

3 Patrick J. Hartin, James and the $Q$ Sayings of Jesus (JSNTSup 47; Sheffield: Sheffield Academic, 1991): 23-35, 42-43; 'Who is wise and understanding among you?' (James 3:13): An Analysis of Wisdom, Eschatology and Apocalypticism in the Epistle of James', in SBL 1996 Seminar Papers (Atlanta: Scholars, 1996): 483-503. T. Y. Mullins takes essentially the same approach as Hartin: 'The factors which merit its classification as Wisdom literature are: its use of proverbs and parables, its teaching of universally applicable moral truths, and its use of traditional Wisdom themes' ('Jewish Wisdom Literature in the New Testament', JBL 68, 1949: 339).

4 Todd Penner, The Epistle of James and Eschatology: Re-reading an Ancient Christian Letter, JSNTSS, 121 (Sheffield: Sheffield Academic, 1996). Though Penner acknowledges that while 'James evinces ... combining and mixing of traditions which is widely attested in the Intertestamental literature ... James utilizes what have been traditionally understood as wisdom themes and forms, this fact in itself does not justify the designation of James as a "wisdom document".' Rather, Penner argues that the sapiential elements in James 'must be viewed within the larger horizon of the eschatological and prophetic framework which undergirds the community instruction of the letter' (222-23). Thus the eschatological bracketing framework for the letter trumps its sapiential qualities. Penner here maintains too strong a dichotomy between the two traditions. Matt Jackson-McCabe, "A Letter to the Twelve Tribes in the Diaspora: Wisdom and "Apocalyptic" Eschatology in the Letter of James', in SBL 1996 Seminar Papers (Atlanta: Scholars, 1996): 504-17; and Donald J. Verseput, 'Wisdom, 4Q185, and the Epistle of James', JBL 117 (1998): 691-707, also question whether it is correct to give the label of wisdom literature to James.

5 Penner, The Epistle of James and Eschatology: 217. Yet, for Penner the 'framework' in which one reads the letter becomes the controlling factor for interpretation. He defines 'framework' as 'the overarching motifs and/or structures which control how material is to be related and interpreted within a particular text. The question of genre is a large part of formulating what the framework of a text is' $(93, n .1)$. Because the 'framework' is eschatological (in the structure of the opening and closing sections), the letter must be read in this light. 
apocalyptic and that one of these elements must control the other. However the view that 'the languages of wisdom and apocalyptic assume different views of the world' 6 can no longer be sustained.

John J. Collins has argued that the distinction between a 'this worldly' wisdom perspective stressing immanence and an 'other worldly' apocalyptic perspective stressing transcendence is an artificial construction which is not found in the literature of the period. ${ }^{7}$ Rather than representing neatly defined genres, current research has been exploring the interrelation between wisdom, eschatology, and apocalyptic. ${ }^{8}$ Furthermore Richard Bauckham has argued:

Just as wisdom teaching does not propound law, so it does not offer apocalyptic revelations of the eschatological future, as many apocalypses do. These are distinctions of genre and function. But just as later wisdom teaching assumes the authority of the law for Jewish life and bases some of its instruction on the law, so later wisdom teaching views the world in an eschatological perspective and attaches eschatological sanctions to its precepts. ... virtually all Jewish thought of the period has an eschatological dimension. ${ }^{9}$

Therefore Bauckham, ${ }^{10}$ and his student Luke Cheung, ${ }^{11}$ have sounded the call for a path of mediation, viewing a greater integration of the sapiential and eschatological elements in James. Thus, it seems that one must not be forced to read James as exclusively emphasizing either wisdom or eschatology but as a wisdom composition incorporating an eschatological perspective of the world.

The present article argues that the presence of sapiential and eschatological material need not be understood as categorically representing different world-views competing in the text, ${ }^{12}$ but rather an eschatological orientation within wisdom paraenesis is to be

6 Burton Mack, The Lost Gospel: The Book of $Q$ and Christian Origins (Shaftsbury: Element, 1993): 31.

7 Seers, Sibyls and Sages in Hellenistic-Roman Judaism (JSJSup, 54; Leiden: Brill, 1997): 385-404; 'Wisdom Reconsidered, in the Light of the Scrolls', DSD 4 (1997): 265-81.

8 John J. Collins, 'Wisdom, Apocalypticism, and Generic Compatibility', in L. G. Perdue, B. B. Scott, and W. J. Wiseman, eds., In the Search of Wisdom: Essays in Memory of John G. Gammie (Louisville: Westminster, 1993): 165-86.

9 Bauckham, James Wisdom of James, Disciple of Jesus the Sage (London: Routledge, 1999): 33 (emphasis added).

10 James: $32-35$.

11 The Genre, Composition and Hermeneutics of James (Carlisle: Paternoster, 2003).

12 See the similar argument by Cheung, Genre, Composition and Hermeneutics: $42-48$. 
expected in the New Testament period. Specifically, this article seeks to contribute to the discussion initiated by Bauckham and others by providing further evidence that sapiential and eschatological elements coexist, and indeed are merged in James. This would, of course, render appeals to structural 'frameworks' to account for the eschatology in James superfluous. ${ }^{13}$ Evidence for this thesis will come from a comparison of the mixture of sapiential and eschatological elements in James and 4QInstruction. ${ }^{14}$ After a brief introduction to 4QInstruction, a comparison of literary forms, thematic content, and motifs will follow. ${ }^{15}$ From this comparison the conclusion will be reached that James, like 4QInstruction, offers wisdom instruction within an eschatological orientation.

13 Cf. Bauckham, James: 34; Cheung, Genre, Composition and Hermeneutics: 48. 'Framework' is Penner's term (The Epistle of James and Eschatology: 93 n. 1, 255).

14 Both of these documents may be described as aphoristic discourses, which strongly resemble Jewish Wisdom paraenesis and therefore are apt candidates for comparison. Cheung argues that an 'aphoristic discourse is usually short and concise, or in a longer text, often it can be divided into individual "units" that can stand in their own right. These are all pungent sayings expressed in the indicative mood, growing out of concrete situations and often conclusions drawn from experience' (Genre, Composition and Hermeneutics: 22-23).

15 Technically aphorisms, admonitions, conditional sayings, etc. are not contentspecific and cannot be labeled as a wisdom literary type, yet the combination of formal features, such as these, and wisdom content work to characterize a document as a whole. James Crenshaw concludes: 'formally, wisdom consists of proverbial sentence or instruction, debate, intellectual reflection; thematically, wisdom comprises selfevident intuitions about mastering life for human betterment, groupings after life's secrets with regard to innocent suffering, grappling with finitude, and quest for truth concealed in the created order and manifested in a feminine persona. When a marriage between form and content exists, there is wisdom literature. Lacking such oneness, a given text participates in biblical wisdom to a greater or lesser extent' (Old Testament Wisdom: An Introduction, Louisville: Westminster John Knox, 1998: 11). 


\section{4QInstruction and James}

The sapiential text 4 QInstruction ${ }^{16}$ represents the longest wisdom document of the Dead Sea Scrolls and has been identified as a 'missing link' in the development of the wisdom tradition between Proverbs and Sirach. ${ }^{17}$ It survives in six (or more) ${ }^{18}$ Hebrew manuscripts, designated 1Q26, 4Q415-418, and 423. Four of these manuscripts are in Herodian script (30-1 BC) with 1Q26 and 4Q423 representing a middle Herodian hand (AD 1-30). The size, which some have compared to the length of the Temple Scroll, ${ }^{19}$ and number of copies of the document have led scholars to believe that, whether or not it was composed at Qumran, it was a very important text for those who kept the cache of documents in the Judean desert. The remains of the document are extremely fragmentary - ranging from fragments the size of a postage stamp to larger pieces containing several columns of text - but have been sufficiently reconstructed to give an idea of the contents of the document. ${ }^{20}$ The majority of the fragments contain literary forms, themes and vocabulary resembling the broader wisdom tradition

16 'Sapiential Work A' was the title given the document before it was officially published in volume 34 of the Discoveries of the Judean Desert series (DJD 34). The editors of DJD 34 have offered the title 'Musar Le-Mevin' (Instruction for a Maven); see John Strugnell and Daniel J. Harrington, Qumran Cave 4.XXIV: Sapiential Texts, Part. 4Qinstruction (Mûsār Lě Mēvîn): 4Q415ff. With a re-edition of 1Q26 (DJD 34; Oxford: Clarendon, 1999): 2-3. Cf. the helpful introductions to 4QInstruction in Matthew J. Goff, The Worldly and Heavenly Wisdom of 4QInstruction (STDJ, 50; Leiden: Brill, 2003); and Daryl F. Jefferies, Wisdom at Qumran: A Form-Critical Analysis of the Admonitions in 4QInstruction (GDNES, 3; Piscataway, NJ: Gorgias, 2002).

17 Strugnell and Harrington, DJD 34:31.

18 Elgvin has argued that there are two copies of 4Qinstruction among the approximately 300 fragments comprising 4Q418 ('The Reconstruction of Sapiential Work A', RevQ 16, 1995: 559-80), while E. Tigchelaar argues for three (To Increase Learning for the Understanding Ones: Reading and_Reconstructing the Fragmentary Early Jewish Sapiential Text 4Qinstruction, STDJ, 44; Leiden: Brill, 2001: 15-17).

19 Strugnell and Harrington, DJD 34:2.

20 Though no complete copy of the Instruction exists, by means of many parallels among the fragments Elgvin has proposed a reconstruction of the text offering a comprehensive outline ('Reconstruction': 579-80). Harrington comments: 'All of the manuscripts of [4QInstruction] are fragmentary. And there are few cases of running text that allow us to see what the sequence of thought was' ('Two Early Jewish Approaches to Wisdom', JSP 16, 1997: 27). However, he goes on to say 'the most common small literary form is the wisdom instruction' which contains 'frequent direct addresses, imperatives and prohibitions, and reasons for following the advice. The material is usually gathered in short units or paragraphs on the various topics ...' (28). From these observations Harrington confidently makes a comparison between the wisdom forms and themes found in 4QInstruction and Sirach. 
including instructions, admonitions with motive clause, didactic sayings, themes regarding the 'poor', wisdom topoi, and instruction on attaining wisdom. Accompanying these aphoristic sections are larger portions of instruction. Finally, scholars have indicated that 4QInstruction especially resembles Sirach, parts of Proverbs, Jesus' instructions in the Synoptic Gospels, and the letter of James. ${ }^{21}$ The text as a whole is characterized by its practical advice and emphasis upon 'revealed wisdom'.

While we are able to discern much regarding the physical characteristics of the text and something of the work's contents based upon the extant fragments, we are not so fortunate to have much information regarding those who composed this text. Though Elgvin believes that the primary themes of the 'pre-teacher' community are reflected in the document, John Strugnell and Daniel Harrington assert that 4QInstruction is not connected to the origins of the community of Qumran. They contend: 'The vocabulary and the thought of 4Q415ff. [4QInstruction] differ decisively from those of the 1-11Q texts; frequently 4Q415ff. has words foreign to the 1-11Q texts or lacks words characteristic of this corpus.' 22 The absence of the special vocabulary of sectarianism and dualism suggests that where 4QInstruction and the other documents discovered at Qumran overlap merely expresses a general non-sectarian and post-exilic sapiential Jewish background. 'Moreover', the editors conclude, 'considered sociologically, 4Q415ff. does not reflect a specific sect or closed community like that of Qumran, nor an earlier quasi-sectarian group. Indeed, it is dubious whether one should talk of communities or groups at all in looking for the background of this work.' ${ }^{23}$ If indeed 4QInstruction originated from a non-sectarian sapiential Jewish background (the view taken here), then possibly the ideas in the text may be more broadly representative of the Second Temple period. Thus 4QInstruction would demonstrate, at least in some circles, that no

21 Daniel J. Harrington, 'Wisdom at Qumran', in E. Ulrich and J. VanderKam, eds., The Community of the Renewed Covenant (Notre Dame: University of Notre Dame, 1994): 144.

22 Strugnell and Harrington, DJD 34:30.

23 Strugnell and Harrington, DJD 34:36. See also Daniel Harrington, Wisdom Texts from Qumran (London: Routledge, 1996): 40-1. Though there is considerable debate concerning whether the document was a product of these individuals, I will follow the lead of Harrington and Strugnell who believe that the Instruction does not originate from Qumran, and thus represents the wider interests of the Second Temple milieu. 
clear world-view boundaries between a sapiential and an eschatological perspective existed.

Likewise, James has often been associated with wisdom literature ${ }^{24}$ and is similar to the aphoristic wisdom of Proverbs and Sirach. It contains instructions, admonitions and exhortations, aphoristic sayings, as well as three longer discourses. James takes up traditional sapiential themes of seeking wisdom and care for the poor. Both texts are best described as wisdom instructions which presuppose a setting where a senior sage addresses either an individual, as in 4QInstruction ('you of understanding', or 'O understanding son') or a group, as in James ('my brothers' or 'my beloved brothers'). ${ }^{25}$

\section{Formal Comparison}

Several formal components shared between our texts make up, what John Gammie has argued, is the secondary genre of paraenetic literature which, in his taxonomy, is a branch of Wisdom Literature. ${ }^{26}$ We may briefly consider some of these.

\section{Admonition and Exhortation}

The most frequent wisdom form in 4QInstruction is the wisdom saying, appearing as admonitions (warning against taking a given course of action) or exhortations (positive command to adopt a given action). Frequently these sayings are formulated in the imperative or jussive, with an accompanying clause or rhetorical question giving motivation

24 J. B. Mayor, The Epistle of St. James (2nd ed. London: Macmillan, 1897): 1xxilxxii, lxxiv-lxxvii; Ulrich Luck, 'Weisheit und Leiden: Zum Problem Paulus und Jakobus', TLZ 92 (1967): 256; Bruce R. Halson, 'The Epistle of James: "Christian Wisdom?"' SE 4 = TU 102 (1968): 308-14; E. Baasland, 'Literarische Form, Thematik und geschichtliche Einordnung des Jakobusbriefes', ANRW 25.2: 3646-84; and Ralph Martin, James (WBC 48; Waco, TX: Word, 1988): lxxxvii-xciii.

25 Johnson comments, 'The group is always being addressed in James even when individual cases are being considered; the exhortation in the majority of ancient paraenetic texts is to the individual' ('The Social World of James: Literary Analysis and Historical Reconstruction', in L. M. White and O. L. Yarbrough, eds., The Social World of the First Christians: Essays in Honor of W. A. Meeks, Minneapolis: Fortress, 1995: 195 n. 78).

26 John G. Gammie, 'Paraenetic Literature: Toward the Morphology of a Secondary Genre', Semeia 50 (1990): 41-77. Though James may be identified as paraenetic literature, this need not imply that the letter has no coherence (contra Martin Dibelius, James: A Commentary on the Epistle of James, tr. Michael A. Williams; 11th ed.; Philadelphia: Fortress, 1976: 2). 
to act upon the wise saying. ${ }^{27}$ There are at least twenty-three such sayings in the remaining fragments of 4QInstruction and at least six clear admonitions in James. ${ }^{28}$ For example:

If you are poor, ${ }^{29}$ do not long for anything but your inheritance, and do not get consumed by it, lest you displace your boundary (4Q416 2 iii 8b$9 a) .{ }^{30}$

\section{And in James:}

Beloved, do not grumble against one another, so that you may not be judged. See, the Judge is standing at the doors! (5:9).

Both passages fit the classic characteristics of the warning admonition. Each begins with the vocative address immediately followed by a vetitive in $4 \mathrm{Q} 416^{31}$ or a negated imperative in James. ${ }^{32}$ Finally, both admonitions are rounded off with a motive clause. ${ }^{33}$ Exhortations are quite common in both documents and significantly, there is no indication of an admonition appearing without a motive clause in either text. $^{34}$

27 Jefferies makes a clear distinction between 'wisdom saying' and 'admonition' (7-9, 90-93), where he sees only 'admonitions' within 4QInstruction, identifying fifty-two full or partial admonitions within the text (Wisdom at Qumran: 115-317, 319).

28 For 4QInstruction: 4Q416 2 i 22-ii 1a; 2 ii 15-21 (several in this passage); 4Q416 2 iii 4, 5-8a; 12b-14a; and for James: 1:19b-20; 4:8a; 4:10; 5:9a; 5:12; 5:16a.

29 In 4Q416, the phrase 'you poor' designates the addressee, functioning like a vocative of address, Eibert Tigchelaar argues that at least seven occurrences of this phrase may be taken to function like the vocative of address, 'The Addressees of 4Qinstruction', in Daniel K. Falk et al., eds., Sapiential, Liturgical and Poetical Texts from Qumran Proceedings of the Third Meeting of the International Organization for Qumran Studies Oslo 1998 (STDJ 35; Leiden: Brill, 2000): 62-75. Likewise in James $5: 9$, we find the characteristic elements of the wisdom saying in the vocative address

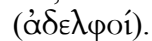

30 All translations of 4QInstruction are taken from Florentino García Martínez in Florentino García Martínez \& Eibert J. C. Tigchelaar, ed., The Dead Sea Scrolls Study Edition (2 vols.; Leiden: Brill, 1997,1998) unless otherwise noted.

31 E.g. the Hitpael imperfect verbal form with the negative particle אל. John G. Gammie refers to this construction as a 'vetitive' (negative imperative) or 'A grammatical mood favored in Hebrew admonitions; the use of the jussive + the negative particle 'al' ('Paraenetic Literature: Toward the Morphology of a Secondary Genre': 71.).

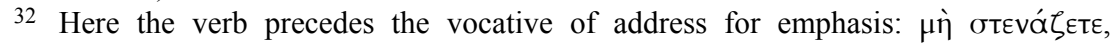

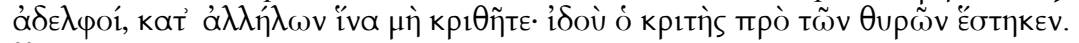

33 In 4Q416 the motive clause is set off by 9 and warns that desiring someone else's share amounts to moving one's boundary. In James the motive clause warns of impending judgement upon those who complain against one another.

34 Further, Jefferies asserts that though the Instruction is partially preserved, 'there is no indication of an admonition without a motive clause' which, according to P. J. Nel, carries the admonition's authority (Jefferies, Wisdom at Qumran: 93-94). 


\section{Future Reversal Sayings}

Both texts contain 'future reversal sayings', which Aune categorizes as a type of aphoristic sentence. ${ }^{35}$ In a reconstruction from both 4Q417 $1 \mathrm{i}$ 10c-12a and the parallel 4Q416 2 i 5c-6 we read:

Gaze upon the mystery that is to come, and comprehend the birth-times of salvation, and know who is to inherit glory and toil. Has not [rejoicing been appointed for the contrite of spirit] and for those among them who mourn eternal joy? 36

Here the contrite and those who mourn are promised joyful rejoicing as their inheritance. Because the future reversal is embedded in an admonition, it serves to encourage the addressee to investigate the raz nihyeh (the mystery that is to be). Though formally this literary type is akin to parallelism, it seems clear that this example is based more upon content rather than a pure form. Regardless, it is evidence of a concern extending beyond a 'this worldly' horizon so common in wisdom literature.

James also contains 'future reversal sayings':

Has not God chosen the poor in the world to be rich in faith and to be heirs of the kingdom that he has promised to those who love him? $(2: 5)^{37}$

Here the poor are designated as ones who will be wealthy with faith and the ultimate heirs of the future kingdom. An example bearing a great resemblance to the instance of future reversal embedded within an admonition in 4QInstruction is the passage found in James 1:9-10, where the ó tarteivós ('the lowly one') is commanded to exalt in his

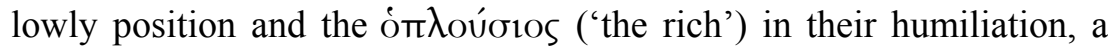
situation set in context by the future judgement of the rich in 5:1-6. Again, though this example is characterized more by content rather than the particular form, it does illustrate an eschatological concern. Passages such as 1:9-10 and 2:5 taken together with 5:1-11 illuminate the final reversal of the 'rich' and 'poor' in James where we can see the eschatological orientation of the traditional concern for the poor where rewards and punishments will be mete out in the life to come.

35 David Aune, 'Oral Tradition and the Aphorisms of Jesus', in H. Wansbroug, ed., Jesus and the Oral Gospel Tradition (JSNTSS 64; Sheffield: JSOT, 1991): 227-36.

36 Translation from Strugnell and Harrington, DJD 34.

37 Cf. Bauckham's catagorization of James 2:5 as 'future reversal saying' (James: 43). 


\section{Other Similar Forms}

In addition to the forms I have highlighted there are several others common to both texts. Both documents use comparison (similitudes) ${ }^{38}$ and each contain step-sayings (sorite): 4Q416 2 ii 18c-21a, ${ }^{39}$ comparable to those found in James 1:2-4 and 1:15. Some have seen a judgement saying in 4Q418 $696-7,40$ with an announcement of judgement in $6 \mathrm{ab}$ and accusation in $6 \mathrm{c}-7^{41}$; which roughly parallels the judgement saying in James 5:1-6, with the announcement of judgement in verses 1-3 and accusation verses 4-6. Also, both texts contain 'measure-for-measure' sayings or 'statements of reciprocity', ${ }^{42}$ which, especially in James, are extended from a 'this worldly' perspective to address God's final judgement. However, where James $(1: 12,25 ; 5: 11)$ and other Qumran wisdom texts (e.g. 4Q525) include beatitudes, 4QInstruction does not include beatitudes in the extant material. Furthermore, where James contains examples and models (paradeigmata), ${ }^{43}$ frequently used in wisdom texts, 4QInstruction does

\footnotetext{
38 4Q416 2 iii 15b-19a; Jas 2:26; 3:4-5a.
}

39 'Do not reach for what is beyond the range of your power, lest you stumble, and your disgrace becomes exceeding[ly] great. [Do not se]ll your sold for money. It is better that you are a servant in the spirit, and that you serve your overseers for nothing. And for money do not sell your glory, and do not mortgage your inheritance for it, lest you bequeath (only) your body. Do not eat your fill of bread, ... when there is no clothing; do not drink wine when there is no food; do not seek delicacies when you ... are in want of bread; do not take pride in your want when you are poor lest you despise your life.'

40 'Your were created [...], and your return will be to the eternal pit, for it shall awaken $[\ldots]$ your $[\mathrm{s}]$ in. The dark places will shriek against your pleadings, and all who exist for ever, who seek the truth will arise to judge y[ou ...]'.

41 Torleif Elgvin argues for a clear announcement of judgement in this passage ('Early Essene Eschatology: Judgement and Salvation according to Sapiential Work A.' Pages 126-65 in Current research and technological developments on the Dead Sea scrolls: conference on the texts from the Judean Desert, STDJ, 20; Leiden: Brill, 1996]: 158). Cf. the translation offered by García Martínez and Tigchelaar: 'You were created [...], and your return will be to the eternal pit ...' 4Q418 127 may also contain a judgement saying.

42 This form is particularly interesting because it indicates both a wisdom and apocalyptic background. David Aune asserts that, 'These pronouncements ... are found in both prophetic and sapiential contexts' and, in his view, 'such "statements of reciprocity" render customary distinctions between wisdom and apocalyptic as questionable' ('Oral Tradition and the Aphorisms of Jesus': 234). Here, following Bauckham, I have adopted the label 'measure-for-measure sayings' because this highlights the thematic link with the OT concept of lex talionis (James: 46-7).

43 James uses the examples of Abraham (2:21-24), Rahab (2:25), the prophets (5:10), Job (5:11), and Elijah (5:17-18). 
not employ any such examples. ${ }^{44}$ Yet, the result of our formal comparison of these two documents shows that they make similar use of several aphoristic literary forms.

\section{Thematic Comparisons}

\section{Wisdom Topoi}

There are several traditional wisdom themes taken up in 4QInstruction. The sage of the Instruction addresses various issues of practical experience including financial matters, ${ }^{45}$ relations within society, ${ }^{46}$ and advice on relating to one's wife ${ }^{47}$ and family. ${ }^{48}$ Because of the fragmentary nature of the text we cannot be certain that these were the main topics of the work as a whole, yet from the surviving texts it appears that the Instruction was concerned with teaching the individual set within the normal context of life. In turning to James, we observe both differences and similarities. James fails to mention several topics of traditional Jewish wisdom, namely financial matters, advice on relating to parents, social superiors, or friends, marriage, or childrearing. Yet, there are some topics common within Jewish wisdom addressed in James, namely the testing of one's faith (1:2), speech ethics $(1: 26,3: 2-12)^{49}$ and warning against anger (1:19-20). Further,

44 In the Jewish wisdom tradition figures from Israel's history are used as wise examples, Tob. 4:12; Sir. 16:5-11; 1 Macc. 2:51-61; 4 Macc. 2:17-19; 16:20-22; 18:1113.

45 Cf. 4Q417 2 i 21b-22 and 4Q416 2 ii 4c-6; 17-18. The setting here of buying and selling, of managing money and the possible reference to the poor selling himself into slavery for the payment of debts echoes a general setting far removed from an isolated sectarian movement.

46 4Q416 2 ii 15b-16; 4Q417 2 i 4.

47 The sage of 4QInstruction assumes the one seeking understanding (mebin) is or will be married. Though married, the 'one who seeks wisdom' is not to be distracted from pursuing the raz nihyeh while keeping company with his wife (4Q416 2 iii 20-21). And echoing the biblical exhortation in Gen. 2:24, the addressee is instructed to "cl[eave to his wife' (4Q416 2 iv 1, par 4Q418 105 ).

48 Echoing the exhortation of the Pentateuch (Exod. 20:12, Deut. 5:16), 4Q416 2 iii $15 \mathrm{~b}-19 \mathrm{a}$ calls the mebin to honour both father and mother.

49 The concern for undisciplined speech is applied specifically to relationships within the Christian community in 4:11-12. Here the 'brothers' are warned not to speak against one another because in their slander they are guilty of judging not only each other but, in doing so, they become judges of the law itself. Moreover, the advice that 'listening is better than speaking' comes under the general topic of speech ethics as 
both texts address the concern for the socially disadvantaged: in James, 'widows and orphans' (1:27), 'the poor' $(2: 2-4,15-16)$, and daylabourers $(5: 4) ;{ }^{50}$ and 4 QInstruction the vulnerable poor $(4 \mathrm{Q} 4162$ ii 17-18).

A key similarity between these two texts is their admonition to seek wisdom. James 1:5 commands: 'If any of you lacks wisdom, let him

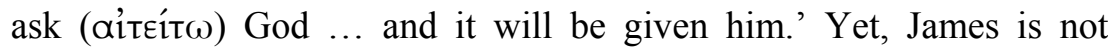
wholly conventional on this topic: instead of the typically 'sapiential' emphasis of a long and intensive search for wisdom, ${ }^{51}$ James advises that God gives wisdom for the asking. ${ }^{52}$ This wisdom is not available within the created order to the one who diligently searches for it, rather the student must ask of God, acknowledging that wisdom is only conferred by the divine. This is further reinforced in 3:17 where wisdom comes 'from above' ( $\dot{\eta}$ óv $\omega \theta \varepsilon v$ oopía), which is to say, from God. ${ }^{53}$ The notion of 'revealed wisdom', more common in apocalyptic literature, is an important theme in James. Though wisdom is not mediated through apocalyptic visions, it comes from God as one of the 'good and perfect' gifts given 'from above, coming down from the Father of lights' (1:17) and therefore is clearly revealed wisdom.

The sage of 4QInstruction exhorts his readers to 'seek wisdom' as well, but, like James, it is clearly an idea moving beyond the traditional, 'this worldly' search for wisdom. The reader is to seek the raz nihyeh; a key phrase occurring over twenty times in 4QInstruction. ${ }^{54}$ The phrase combines the word raz (זר, 'mystery')

well. In Jas 1:19 the 'beloved brothers' are told to be quick to hear and slow to speak and to anger.

50 In the context of a judgement oracle James reflects on the unjust treatment of those who are economically dependent upon the landed aristocrats and yet who are denied their wages. 4QInstruction may bear the same concern ef. 4Q416 2 ii 17-18, par. $4 \mathrm{Q} 4167$ ii 5-6.

51 Cf. Prov. 2:1-5; 8:34; Sir. 6:18-37; 39:1-7; Wis. 6:9-16.

52 Bauckham, James: 96.

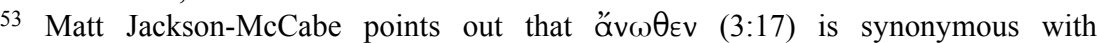

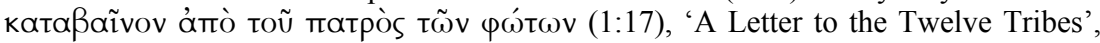
508 n. 36.

54 Cf. 4Q415 6 4; 4Q415 24 1; 4Q416 2 i 5; 4Q416 2 iii 9, 14, 18 (par 4Q418 10 1), 21; 4Q417 1 i 8, 18, 21 (par 4Q418 43 6, 14, 16); 4Q417 1 ii 3; 4Q418 43 4; 4Q418 77 2, 4; 4Q418 123 ii 4; 4Q418 172 1; 4Q418 184 2; 4Q418 201 1; and 4Q423 4 1, 4 (par 1Q26 $1 \mathrm{i}, 4)$. The phrase may also appear in the following reconstructions: 4Q417 $1 \mathrm{i}$ 3, 6; 4Q417 2 i 10-11; 4Q418 179 3; 4Q418 190 2-3; 4Q423 5 2; and 4Q423 7 7. The phrase occurs only four times elsewhere in Qumran documents; once in the Book of Mysteries and three times in the Community Rule (1QS 1 i 3-4 [twice] (par 4Q300 3 4); 1QS 11:3-4). 
with the Niphal participle of the verb 'to be' (הידה). Though several scholars have suggested various translations and interpretations of the phrase, ${ }^{55}$ it is often translated 'the mystery to be/become' referring to the revelation of heavenly knowledge concerning 'all the paths of truth and observe closely all the roots of injustice' (4Q416 2 iii 14b). The moment of this revelation has already occurred yet neither the event of revelation nor its contents is ever described. Though we could consider whether the raz nihyeh is a written document, either associated with the Torah or an independent compendium of wisdom, in the end the raz nihyeh and the command to seek it, demonstrates an eschatological world-view operating in 4QInstruction in at least two distinct ways. First, understanding is revealed from God and not found within creation. Second, the function of the raz nihyeh is understood to produce the knowledge of eschatological realities, namely knowledge of the 'birth-time of salvation', and who is 'to inherit glory and trouble'. Here we see both documents mixing the ethical and practical exhortation to seek wisdom with an eschatological frame of reference, namely that this wisdom is revealed.

\section{Eschatological Themes}

First it must be said that neither of these texts present a full-blown eschatological discourse but, equally, that both texts reference 'revealed wisdom', final judgement, and future expectation within the general context of instruction. Thus, we can see that the interest in

55 See the helpful survey of scholarship in Goff, Worldly and Heavenly Wisdom; Jefferies, Wisdom at Qumran. This phrase has been understood to refer to a future revelation, as the pre-existent sapiential order of creation, principles embedded in the Torah/or the Torah itself. However, it seems unlikely that the expression was associated strictly with a written body of text because the raz nihyeh includes divine knowledge to discern between good and evil (4Q416 2 i 5-6), and it reveals aspects of the origin and history of humankind (4Q418 772 ). The raz nihyeh is further described in 4Q417 1 i 8-9 (par 4Q418 43 6-7): 'the God of knowledge is a foundation of truth and by the mystery that is to be he has made distinct its foundation and its deeds ....' (author's translation). Therefore the raz nihyeh is associated with past creation and cannot be understood in strictly futuristic terms. Furthermore, the expression וכול 'everything that ever came into being' (4Q418 69 6) seems to clearly indicate that raz_nihyeh cannot be understood in a purely futuristic sense. Yet the raz nihyeh though connected with creation has eschatological qualities: through it God reveals understanding regarding the periods of time (קצים, 4Q418 123 ii 2), the origin of salvation, including who will inherit glory and corruption (4Q417 2 i 10-12), and the difference between truth and iniquity in order to discern both the 'good' from the 'bad' (4Q417 1 i 5-8b, 10b-11a). 
eschatology fits within a spectrum of sapiential and eschatological concerns in the text. ${ }^{56}$

The fragmentary beginning of 4Q416 relates a description of the orderly creation and courses of nature in accordance with God's will. ${ }^{57}$ It is evident that the context of the passage is a description of creation and the consequent orderly courses of nature. ${ }^{58}$ However in line 10 the text shifts to consider the final judgement:

In heaven he passes judgement upon the work of iniquity, and all the sons of his truth will be favourable [...] its end. And all who have defiled themselves with it will be in dread and cry out, for (the) heavens will fear [...] [s]eas and abyss are in dread, and every spirit of flesh will be stirred up, and the sons of the heavens [... on the day of] its [judg]ment. And all injustice will end again, and the time of tru[th] will be complete [...] in all periods of eternity, for he is the God of truth and from ancient times (are) [his] years [...] to establish justice between good and ev[il], to ...every judg[ment] (4Q416 1 10-15).

Here, in the traditional wisdom context of orderly creation, the author makes an allusion to the final judgement upon the wicked. Tigchelaar observes 'The eschatological section of the introduction may be seen as supplementary to the cosmological part ${ }^{59}$ and thus may be seen as an example of the mixing an eschatological concern with the traditionally sapiential theme of God's orderly creation. There is also an example of future hope for the righteous:

... how can you say: we have toiled for insight, and been vigilant to pursue knowledge [...] in all [...] and does not tire in all years of eternity; does he not take delight in truth forever, and knowledge [...] serves him. And the s[ons of] heaven whose inheritance is eternal life, would they really say: «We have toiled for the works of truth, and [we] have tired (ourselves) in all times?» (4Q418 69 11b-14a).

56 In Jefferies' analysis, 'While reflecting the traditional forms of wisdom, 4QInstruction functions within an apocalyptic worldview' (Wisdom at Qumran, 63).

57 Tigchelaar, To Increase Learning.

58 This is a common wisdom theme (cf. Sir. 16:26-28; 43:1-10; 1QS 10 1; 1QM 118 ; $1 \mathrm{QH}^{\mathrm{a}} 9$ 25-26, 20 7. Cf. 1 Enoch 1-5 for a similar connection).

59 To Increase Learning: 185. It is interesting to compare Elgvin's reconstruction and translation with the DJD reconstruction. Tigchelaar's comments are most appropriate: 'Elgvin takes a maximalist approach, interpreting these and other references eschatologically, and often reconstructing lacunae in such a manner that the reconstructed text becomes eschatological ...' (186). Elgvin's work must be handled with this in mind. 
Where the Instruction reflects the traditional sapiential concern for preserving one's name after death (4Q417 4 ii 3; cf. 4Q416 2 iii 7) $)^{60}$ this theme is accompanied in the text by the assurance that one can obtain 'eternal joy' (4Q417 $1 \mathrm{i} 10-12$ ), as in the passage above, the 'inheritance' of 'eternal life'. Though concerns for future judgement of the wicked and vindication of the righteous are not the primary focus in 4QInstruction, the motivation for ethical conduct is provided by the eschatological anticipation of judgement and reward. ${ }^{61}$

James likewise voices warning of final judgement upon the wicked. In 5:1-6 the rich are told to 'weep and wail' because the deterioration of their wealth and possessions will become evidence against them, and this 'corrosion' (’ós) 'will consume ( $\varphi a ́ \gamma \in \tau a l)$ their flesh like fire' (5:3). The rich are castigated: 'You have laid up treasure for the last days' (5:3b). What the rich normally would glory in, their treasure, ironically indicates their impending judgement, and that, in 'the last days'. Here the idea of retribution for evil deeds done in this life (specifically here keeping back the wages of the day-labourer) is set within the future context of God's final judgement. ${ }^{62}$ James also reflects future hope for the righteous by means of expecting the return of the Lord, 5:7-11. Here the addressees are encouraged to be patient during the interval of time before the Lord's coming. ${ }^{63}$ Thus in both passages, ethical conduct is given eschatological motivation, namely judgement for the former, and the Lord's coming for the latter.

\section{The 'Two Ways' Motif}

A common motif functioning in wisdom and apocalyptic literature is the contrast of the 'two ways'. This motif is often found in moral

60 Cf. Prov. 10:7; Sir. 6:1; 15:6; 41:11.

61 Bauckham makes a very interesting statement when he asserts that, 'Eschatological judgement is when the real truth of this life is revealed and receives what is finally due to it. This is final justice. Of course, the idea no doubt has also a kind of paraenetic function. Everything is really decided already in this life; and so the need to live well in this life is absolute' (Fate of the Dead: Studies on the Jewish and Christian Apocalypses, NovTSup 93; Leiden: Brill, 1998: 210).

62 'Judgement oracles addressed to the wicked', Bauckham asserts, 'are not characteristic of wisdom literature, though 'woe' sayings occasionally occur (Eccl. 10:16; Sir. 2:12-14; 4Q185 1-2:9-13)' (Bauckham, James: 57).

63 Whether kúpios here refers to God or Jesus, as both are referred to as kúpios (1:1; 2:1 of Jesus and 1:7 of God), is questionable. Based upon several uses in the NT, Johnson asserts, 'It is certainly the case ... that James' double use of parousia tou kyriou in 5:7-8 reflects a virtually technical Christian usage and, in all likelihood, refers to the coming of Jesus as judge' (Johnson, The Letter of James: 314). 
instruction contrasting positive and negative ways of living in order to illustrate to young students the way of virtue. The 'two ways' motif draws upon the covenantal choice between life and death (Deut. 30:1520) and becomes a common metaphor in wisdom, apocalyptic and Christian paraenetic texts. ${ }^{64}$ QQ418 69 preserves a discourse contrasting the upright and the foolish. The main part of the fragment consists of instructions directed first to the 'foolish of heart, ${ }^{65}$ and then to the 'truly chosen ones.' ${ }^{66}$ The foolish are warned that their way will end in ruin:

The dark places will shriek against your pleadings, and all who exist for ever, who seek the truth will arise to judge y[ou. Then] all the foolish of heart will be annihilated, and the sons of iniquity will not be found any more. [And a]ll who clung to evil will be ashamed. [And then,] at your judgement the foundations of the firmament will shout, and all [...] (4Q418 69 ii 7-9a).

However, those who pursue righteousness and understanding will be rewarded with the right to walk in the presence of angels. And this is said of the 'chosen ones of truth':

Do $[\mathrm{t}] \mathrm{he}[\mathrm{y}]$ not wal $[\mathrm{k}]$ in eternal light $[\ldots \mathrm{gl}]$ ory and abundant splendor? You $[\ldots]$ in the firmaments of $[\ldots$ in] the council of the gods is all $[\ldots]$ (14).

The promise of judgement and reward presents a dualistic contrast between the fates of the 'foolish of heart' and 'chosen ones of truth'. In contrast with the traditional portrayal of the 'two ways' in wisdom literature, the 'wise' are replaced with those who are 'chosen' and their ultimate reward or punishment is placed in an eschatological context.

In James, the 'two ways' tradition is woven throughout the text, appearing in the contrast between wholeness and double-mindedness $(1: 4,7-8 ; 4: 8)$, hearing and doing (1:22-25), two kinds of faith $(2: 14-$ 26), friendship with the world and friendship with God (4:4), the rich and the poor $(1: 9-11 ; 2: 5 ; 5: 1-6)$, and in the climatic implicit contrast between the way of error and the way of truth $(5: 19-20)$. Throughout the letter, the choice between the way of life and the way of death is on

64 M. J. Wilkins, 'Teaching, Paraenesis', in Ralph P. Martin, Peter H. Davids, eds., Dictionary of the Later New Testament \& Its Developments, (Downers Grove: IVP) on CD-ROM. Version 2.1c. 1998, c1992.

אוילי לב 65 lines 4-9, also called 'sons of iniquity', and 'those who cling to evil.'

66 בחירי אמרי אמב, lines 10-15, also the 'pursuers of ...', and 'the searchers of ...'. Strugnell and Harrington suggest 'you who are chosen by Truth', 'truly chosen ones', or 'those who choose truth', as possible translations. 
offer by the author and the climax of such an offer is extended from retribution in this life to final judgement in the next (cf. 5:1-6). ${ }^{67}$ The oppositional nature of the 'two way' motif is further displayed in the discourse on wisdom in 3:13-17, where 'wisdom from above' is contrasted with a wisdom that is 'earthly'. Such a contrast corresponds to the perception of wisdom as the measure of human behavior. ${ }^{68}$ Yet, as the 'good and perfect' gifts in 1:17, this wisdom is 'wisdom from above' ('̊ $v \omega \theta \varepsilon v$ бopía, 3:15, 17), while 'jealousy' and 'selfish ambition' outwardly characterize the antithesis of 'wisdom from above', namely wisdom that is 'earthly, unspiritual, devilish'

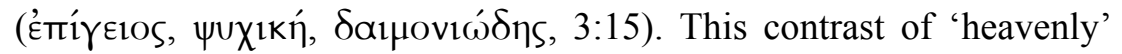
and 'demonic' is essentially an invitation to follow one of two ways. The way of 'wisdom from above' or the way of the 'earthly, unspiritual, devilish'. The contrast of the two 'ways of wisdom' supports an eschatological dualism similar to that found in 4QInstruction and once again provides an example of the mixing of eschatological concerns with a motif traditionally associated with sapiential literature.

\section{Conclusion}

This study has demonstrated several literary forms, themes, and motifs shared between 4QInstruction and James; namely admonitions and exhortations, future reversal sayings, aphoristic sentences, traditional wisdom topoi, eschatological themes, and the 'two ways' motif. From these similarities it seems that both texts incorporate traditional sapiential wisdom concepts with an eschatological understanding of the world. The mixing of ideas is particularly evident in each text's portrayal of 'revealed wisdom' and the eschatological judgement of the wicked and righteous. Thus, the eschatological elements in James are not limited to the prologue and epilogue (as argued by Penner) but

67 Penner states that, "James ... may be understood as a "two ways" document ... The writer conceives of a path to life and one to death, and urges the readers to choose the one which leads to blessing' (The Epistle of James and Eschatology: 232). Cf. the assessment of Margaret Mary McKenna, that James in entirely composed of 'two ways' elements, including antithesis and imagery and metaphor of 'way' (“"The Two Ways" in Jewish and Christian Writings of the Greco-Roman Period: A Study of the Form Repentance Paraenesis' (unpublished Ph.D. dissertation, University of Pennsylvania, Department of Classics, 1981): 268.

68 Prov. 1:7; 2:6; 22:4; Sir. 1:1, 14, 26; 19:20; Wis. 1:6; 7:15. 
undergird the entire work functioning as the motivation for ethical behavior. In spite of the fragmentary nature of 4QInstruction it appears that the eschatological elements again undergird the entire document similarly functioning as motivation for ethical conduct. Therefore, to pit wisdom and eschatological elements against one another or to postulate an overarching framework within which one element (eschatology) brackets the other (wisdom, again, cf. Penner) does not fit what we know about wisdom teachings from Qumran. Such moves betray an assumption that the elements are not compatible. Rather, we must think of a continuous spectrum, a sliding scale, in which elements of traditional wisdom and eschatological world-views are intermingling. ${ }^{69}$

James should neither be viewed as novel in combining these two traditions nor be disqualified as a wisdom document. That is to say, it was a recognized move within the general milieu of Second Temple Judaism to mix or incorporate sapiential motifs to include an eschatological view of reality. Thus James, as wisdom paraenesis, need not be disqualified as a wisdom writing based upon the presence of and emphasis upon an eschatological world-view. ${ }^{70}$ The present article has offered further evidence for such a conclusion by demonstrating how both 4QInstruction and James incorporate traditional sapiential themes with an eschatological world-view.

69 I owe this language to Bauckham, James: 34.

70 Cf. Bauckham, James: 34; Harrington, Wisdom Texts from Qumran: 90-91; Cheung, Genre, Composition and Hermeneutics: 42-48. 